\title{
THE NEعD FOR SPECIFIC ACCOUNTING PRINCIPLES FOR NON-PROFIT ORGANISATIONS’ ASSETS WITHOUT ECONOMIC BENEFITS, RESTRICTED DONATIONS AND FUNDS
}

\author{
Cobus Rossouw* \\ University of the Free State \\ rossouwj@ufs.ac.za
}

Received: November 2012

Accepted: April 2013

\begin{abstract}
Non-profit (or "not-for-profit") organisations are faced with specific challenges in their financial reporting when they are required to or chose to apply formal financial reporting standards. The IFRSs or the IFRS for SMEs are meant for business entities and are not specifically developed to be applicable to non-profit organisations. Prior research suggested that the main problems of nonprofit accounting centre on the recognition of assets with no future economic benefits, but with service potential, the recognition of restricted income and the so-called fund accounting. This research analyses the requirements of IFRSs, IFRS for SMEs and the Australian accounting standards for non-profit organisation relating to these aspects. The article then presents the views of South African accounting practitioners who are involved in the financial reporting of non-profit organisations on these issues.
\end{abstract}

Keywords

Accounting for non-profit organisations / not-for-profit organisations; Differential reporting; Financial reporting; Fund accounting; Donations; Service potential.

\#Prof Cobus Rossouw is an associate professor at the Centre for Accounting, University of the Free State, Bloemfontein, South Africa. 


\section{INTRODUCTION AND BACKGROUND}

A non-profit or not-for-profit organisation can be described as any organisation whose principal objective is not the generation of profit (Institute of Chartered Accountants in Australia, 2006; AASB, 2009). The South African Non-profit Organisations Act defines a nonprofit organisation "as a trust, company or other association of persons established for a public purpose and of which its income and property are not distributable to its members or office bearers except as reasonable compensation for services rendered" (RSA, 1997). More precisely, the purpose of these organisations is not to generate profits for distribution to equity participants, but rather to fulfil social, educational, religious, health or philanthropic purposes (Institute of Chartered Accountants in Australia, 2006; Rossouw, 2008).

As far as financial reporting is concern, South African non-profit organisations may feel like orphans - abandoned and left behind. Amidst all the recent South African developments of financial reporting standards for business entities (the "for-profit entities", for example, the establishment of differential reporting, the adoption of the International Financial Reporting Standard for Small and Medium-sized Entities (IFRS for SMEs), various attempts at the so-called "micro-gaap", constant improvements in International Financial Reporting Standards (IFRSs), etc.) the financial reporting of non-profit organisations has received no attention. Formal financial reporting standards applicable in South Africa are basically the IFRSs or the IFRS for SMEs, which are not designed to apply to non-profit organisations, but to profit-orientated entities (Lee \& Teixeira, 2004). However, it seems that current legislation for registered nonprofit organisations (RSA, 1997) requires compliance with "standards of generally accepted accounting practices" (section 17). Non-profit organisations are therefore left with the challenge of applying accounting standards that are not specifically developed for them and perhaps not appropriate to them. It may be no surprise that the Department of Social Welfare found that the reporting requirements are particularly difficult for non-profit organisations to comply with (Department of Social Development, 2005).

Currently there is no financial reporting framework that applies specifically to non-profit organisations in South Africa. In addition to this, there seem to be a lack of research on the unique and specific reporting needs of non-profit organisations in South Africa. Related research elsewhere (Mautz, 1989, Institute of Chartered Accountants in Australia, 2006) suggests that there is a need for a suitable financial reporting framework that meets the specific requirements of non-profit organisations.

Prior related research in South Africa (Rossouw, 2006a) confirmed this and suggested that nonprofit organisations do have specific accounting needs and that specific accounting principles for non-profit organisation may be relevant. The format of specific accounting principles could be achieved in different ways - for example, by amending IFRSs to incorporate specific principles or by issuing separate standards for non-profit organisations. The actual format of specific accounting principles for non-profit organisation, however, is beyond the scope of this research and is an area for future research. This prior research also suggested that the main problems of non-profit accounting are in the following three areas (Rossouw, 2006a:235-237):

- the recognition of assets with no future economic benefits (either directly or indirectly), but with service potential (Mautz, 1989; Lee \& Teixeira, 2004; Rossouw, 2008);

- the recognition of restricted income (Lee \& Teixeira, 2004; Rossouw, 2006b; Rossouw, 2007); and 
- the so-called fund accounting (Mautz, 1989; Leo \& Addison, 2000; Rossouw, 2006b; Rossouw, 2007).

This article therefore analyses the reporting requirements relating to these areas and presents the views of a sample of the accounting practitioners dealing with the financial reporting of these organisations. The article is structured as follows: the research objectives and method will be outlined in section 2, after which the literature review will be presented. The next section deals the empirical research, after which the findings of the empirical research on the practitioners' views on the financial reporting of non-profit organisations will be discussed. A summary and conclusion are formulated in the last section of the article.

\section{RESEARCH OBJECTIVES AND METHOD}

The main purpose of this article is to provide a literature review of and empirical data on the accounting practitioners' views on the following areas in the financial reporting of non-profit organisations:

- the need for specific accounting principles (in the format of standards or guidelines) for non-profit organisations;

- the concept of service potential rather than economic benefits as a criterion for the recognition of assets;

- the recognition of restricted donations; and

- fund accounting.

To achieve these stated research objectives, a literature review was conducted. South African literature on the financial reporting for non-profit organisations is somewhat limited, and, therefore, specific focus was placed on the Australian Accounting Standards for non-profit organisations (see section 3). Empirical research was conducted to obtain the views of a sample of accounting practitioners who are involved in the financial reporting of non-profit organisations. The method and the empirical results are outlined in sections 4 and 5 respectively.

This article therefore contributes to the existing theoretical accounting literature on the financial reporting of non-profit organisations, as various reporting standards and their application to specific accounting aspects within these organisations were analysed. Furthermore, valuable empirical data on the views of accounting practitioners is presented.

\section{LITERATURE REVIEW}

A literature review was conducted in order to determine the unique areas in accounting principles of non-profit organisations. The literature review specifically deals with the four aspects identified in the research objectives above.

It was mentioned in the introduction and background section that IFRSs and the IFRS for SMEs are the only formal financial reporting standards in South Africa. Furthermore, it was mentioned that these standards are designed for "for-profit" entities and are not specifically appropriate to non-profit organisations. These standards do not provide any specific accounting principles 
on aspects that are unique to non-profit organisations. This implies that non-profit organisations need to develop their own accounting principles to be applied to their unique or specific transactions.

As a result of the lack of specific accounting guidance for non-profit organisations, they would arguably need to refer to guidance within IFRSs (as the general body of accounting knowledge) for developing their own accounting principles. IAS 8 states that in the absence of an IFRS that specifically applies to a transaction, other event or condition (IFRSs do not address assets with service potential, restricted donations and fund accounting), management shall use its judgement in developing and applying an accounting policy that results in information that is relevant to the economic decision-making needs of users and that is reliable (IASB, 201la). In developing such accounting policies management shall refer to

- the requirements in IFRSs dealing with similar and related issues;

- the definitions, recognition criteria and measurement concepts of the Conceptual Framework for assets, liabilities, income and expenses; and

- the most recent pronouncements of other standard-setting bodies that use a similar conceptual framework to develop accounting standards.

The first two points of reference above (i.e. the IFRSs and the Conceptual Framework on which the individual IFRSs are based) are not specifically designed to apply to non-profit organisations. Consequently, this research will refer to the "pronouncements of other standardsetting bodies that use a similar conceptual framework" in considering the three identified areas (assets' service potential, recognition of donations with performance conditions, and fund accounting - see section 2). Prior research (Rossouw, 2006a) has identified other standard-setting bodies that have issued specific accounting concepts for non-profit organisations as the United States of America (US), Canada, the United Kingdom (UK) and Australia). From analysing the US, Canadian and UK standards for non-profit organisations, the author found that these standards were not based on the current IFRSs (that are applied in South Africa) and were thus not considered to be fully appropriate in meeting the approach as stated (third bullet) above. Similar to South Africa, the Australian reporting framework is based on IFRSs. The AIFRS (Australian equivalent to IFRS) contains specific accounting principles for non-profit organisations (Institute of Chartered Accountants in Australia, 2006:7). The Australian standards for non-profit organisation in particular were thus considered to be an appropriate framework to be considered for developing accounting policies for the areas identified in meeting the objectives of this research. The rest of this section is therefore structured in the same sequence as the research objectives were presented in section 2 above.

\subsection{Specific accounting principles for non-profit organisations}

The Non-profit Organisations Act (RSA, 1997) stipulates that non-profit organisations have to comply with "standards of generally accepted accounting practices" in preparing their financial reports (section 17; emphasis added). Formal standards applicable in South Africa are basically the IFRSs or IFRS for SMEs. However, these standards specifically state that "IFRSs are designed to apply to the general purpose financial statements and other financial reporting of profitoriented entities... Although IFRSs are not designed to apply to not-for-profit activities in the private sector, public sector or government, entities with such activities may find them appropriate" (IASB, 2011 b: par. 9; emphasis added). 
Traditionally there has been only one set of accounting standards for all entities (irrespective of their nature, size, sector, etc.). Over the past two decades South Africa has moved from the (old) South African Statements of Generally Accepted Accounting Practice (SA GAAP) to the IFRSs and has also adopted the IFRS for SMEs. However, the financial reporting of non-profit organisations received no attention and specific accounting principles or guidance does not currently exist in South Africa.

A non-profit organisation may exist in the form a company under the Companies Act (RSA, 2008). The financial reporting requirements for non-profit companies are similar to other companies in that non-profit companies also need to determine their "public interest score" as a measure of their public accountability. Non-profit companies with a higher level of public accountability are then also required to comply with IFRSs or IFRS for SMEs, depending on their score. The lowest level of non-profit companies (with a public interest score of less than 100 whose financial statements are internally compiled) can determine their own reporting framework and their own accounting policies (regulation 26-27) (RSA, 2011). The purpose of this research is to obtain accounting practitioners' views on specific accounting standards in cases where compliance with formal standards are required and not to address the specific nature of small (or micro) and non-public companies (albeit non-profit companies).

In Australia and New Zealand, for example, the need for a suitable financial reporting framework that meets the specific requirements of non-profit organisations has already been identified. The New Zealand equivalent to IFRSs is sector-neutral and applies equally to for-profit entities and non-profit organisations (Lee \& Teixeira, 2004; Carson, 2008; Accounting Standards Review Board, 2009). However, seeing that the IFRSs are developed for application by profit-oriented entities (as mentioned above), the New Zealand Accounting Standards Review Board is of the opinion that it may in some cases be necessary to modify some IFRSs or to introduce additional requirements on recognition and measurement concepts to be applicable to non-profit entities. It also believes that the intended overall effect of modifying or introducing additional requirements for these entities should be to reflect differences between the sectors, including differences in the information needs of users that warrant a different accounting treatment or additional guidance (Accounting Standards Review Board, 2009).

This view was also confirmed by the Australian Accounting Standards Board of the Australian Government and by the Financial Reporting Standards Board of the New Zealand Institute of Chartered Accountants in a joint discussion on the process for modifying IFRSs for public benefit entities and not-for-profit entities (AASB, 2009). Moreover, the Australian standard setters had some time before already recognised that non-profit organisations have different objectives compared to business entities and use their resources differently in achieving their objectives. This recognition has already led to the inclusion of specific accounting principles in many of the Australian accounting standards that are specific to non-profit organisations (Institute of Chartered Accountants in Australia, 2006).

Lee and Teixeira (2004) argue that there are differences in the operating objectives of certain types of entities and it is important that the financial information that are presented reflect those objectives. It should be borne in mind that non-profit organisations exist for a different reason (given the nature and characteristics thereof, as was indicated in the introduction and background section of this article). Carson (2008:22) takes it one step further and is of the view that, ideally, there should be three sets of financial reporting standards: one for profitorientated entities, one for public sector non-profit entities and one for private sector nonprofit entities. Considering specific standards for non-profit entities in the public versus private 
sector is beyond the scope of this article. Following the unique nature of non-profit organisations, it may be relevant to consider differential reporting based on the nature of a non-profit organisation. This aspect is an area for future research.

It is considered that all non-profit organisations that report publicly should have some financial reporting requirements (Carson, 2008). This is in line with the current financial reporting requirements in terms of the Companies Regulations with "higher" standards applicable to entities with a higher level of public accountability as was discussed above. However, the existing standards (the IFRSs) are not considered to adequately address the needs of users of the financial statements of non-profit organisations (Carson, 2008). Lee and Teixeira (2004) also argue that specific guidance tailored to address the accounting issues of non-profit organisations is needed.

From the literature it can be concluded that specific accounting principles for non-profit organisation may be needed. The empirical results of the accounting practitioners' views on this aspect are presented in section 5.1 below.

\subsection{Recognition of assets and their service potential}

Future economic benefit is a key component of an asset in terms of the definition of an asset in the Conceptual Framework for Financial Reporting (IASB, 2010). An asset is defined as "a resource controlled by the entity as a result of past events and from which future economic benefits are expected to flow to the entity" (emphasis added). The future economic benefits embodied in an asset are then described as the potential to contribute, directly or indirectly, to cash flows of the entity. Applying this definition implies that an asset without economic benefit (direct or indirect cash inflows) would not be recognised in the financial statements as such, as it would fail the definition of this element.

In contrast, one of the main characteristics of the assets of non-profit organisations is the fact that their assets may not necessarily be used to generate future economic benefits. A non-profit organisation, based on its nature and purpose of existence, may very well use an asset to fulfil its stated objectives rather than to generate economic benefits (i.e. cash flows) (Rossouw, 2008). For example, a welfare organisation may exist to provide food parcels to the poor. The vehicle it uses to deliver the food parcels does not generate future economic benefits as such, but enables the entity to do what it is supposed to do. Mautz (1994:15-16) describes these types of assets instead as "cash consumers" rather than assets with expected cash inflows. Mautz (1989:61) also refers to these kind of assets as "looks like a duck and walks like a duck, but it doesn't lay duck eggs." Instead of providing economic benefits, such assets have "an insatiable appetite for cash expenditure". Other assets (inventory) of a non-profit organisation may very well be acquired to be given away for free (for example, the food parcels to be delivered to the poor). Despite this, these assets of non-profit organisations may still be regarded as being valuable to the entity and acquired specifically to enable the entity to meets its objectives (Mautz, 1994:42-44, Granof, 2001:6). This concept is referred to as the asset having "service potential".

Even though IFRSs focus purely on economic benefits, limited reference is made to the concept of service potential (although somewhat disguised). The only reference in the standards itself is found in IAS 36 Impairment of Assets. Reference is made to service potential in determining the recoverable amount and reversal of impairment losses. Limited references to service potential are also found in the basis for conclusions to IFRS 1 First-time Adoption of International 
Financial Reporting Standards, IAS 16 Property, Plant and Equipment and IAS 36 Impairment of Assets (IASB, 2011c).

As mentioned above, the Australian standards (AASB) have specific accounting principles for non-profit organisations, and these standards were considered to be appropriate as a point of reference in developing specific accounting policies for South African non-profit organisations. From an analysis by the author of the Australian standards it can be deduced that the general concept is that assets provide a means for non-profit entities to achieve their stated objectives. The definition of an asset in terms of the general Conceptual Framework has been modified as follows: "In respect of not-for-profit entities in the public or private sector, in pursuing their objectives, goods and services are provided that have the capacity to satisfy human wants and needs. Assets provide a means for entities to achieve their objectives. Future economic benefits or service potential is the essence of assets. Future economic benefits is synonymous with the notion of service potential, and is used in this Framework as a reference also to service potential. Future economic benefits can be described as the scarce capacity to provide benefits to the entities that use them, and is common to all assets irrespective of their physical or other form" (AASB, 2011; emphasis added).

From an analysis of the Australian standards the author found that this general concept was then followed through in developing specific accounting principles that deal with the following:

- Inventories held for distribution (AASB 102 Inventories). This represents inventories held for distribution by not-for-profit entities at no charge or for a nominal amount. Such inventories are to be valued at the lower of cost or current replacement cost (instead of net realisable value, as the items will not be "sold" in the true sense of the word). Replacement cost is to be used where the inventories are acquired for no or nominal consideration.

- Recognition of property, plant and equipment, intangible assets and investment property on acquisition (AASB 116 Property, Plant and Equipment, AASB 138 Intangible Assets and AASB 140 Investment Property). Where a not-for-profit entity acquires an asset at no cost, or for a nominal cost, the cost is its fair value as at the date of acquisition. This requirement arguably stems from the fact that these entities may often receive assets for no or nominal consideration based on their nature as non-profit organisations.

- Use of depreciated replacement cost for impairment of assets (AASB 136 Impairment of Assets). An asset's "value in use" is not determined as its recoverable amount, but rather the depreciated replacement cost. Value in use for these entities is the depreciated replacement cost of an asset when the future economic benefits of the asset are not primarily dependent on the asset's ability to generate net cash inflows and where the entity would, if deprived of the asset, replace its remaining future economic benefits. Depreciated replacement cost is defined as "the current replacement cost of an asset less, where applicable, accumulated depreciation calculated on the basis of such cost to reflect the already consumed or expired future economic benefits of the asset".

- Properties that do not meet the definition of an investment property (AASB 140 Investment Property). This standard determines that in respect of not-for-profit entities, property may be held to meet service delivery objectives rather than to earn rental or for capital appreciation. In such situations the property will not meet the definition of investment property and will be accounted for under AASB 116 (as property, plant and equipment), for example: (a) property held for strategic purposes; and (b) property held to provide a social service, including those which generate cash inflows where the rental revenue is incidental 
to the purpose for holding the property (an example of such an asset may be houses held by an old-age home for providing housing to the elderly at a nominal monthly rent).

Although the distinction between non-profit organisations in the public versus private sector is beyond the scope of this article, it may be relevant to consider the public sector accounting standards in this regard. South African entities in the public sector are required to comply with Standards of Generally Recognised Accounting Practice (GRAP) (ASB, 2012a). It is interesting to note that the concept of service potential is fully included in GRAP. The definition of an asset in terms of GRAP refers to economic benefits or service potential. Assets are defined as "resources controlled by the entity as a result of past events and from which future economic benefits or service potentia/ are expected to flow to the entity" (ASB, 2012b; emphasis added). It is thus clear that the GRAP also recognised the fact that the assets of public sector entities could either produce economic benefits or it could enable an entity to fulfil its reason for existence by enabling the entity to fulfil a public need (for example, a museum).

It can be deduced that the benefits from an asset's service potential equates with economic benefits for entities that are not only in business for generating profits for their equity participants, as is the case for non-profit organisations. The empirical results of the accounting practitioners' views on this aspect are presented in section 5.2 below. The next specific accounting aspect of non-profit organisations that is discussed is the recognition of donations.

\subsection{Recognition of donations as income}

Perhaps the most distinctive characteristic of non-profit organisations is the fact that they often receive donations or gifts, which is uncommon in the business environment (Ives, Razek \& Hosch, 2004). Donors would donate money or goods in kind to the non-profit organisation based on the reason for which the non-profit organisation exists, for example donors donate money to a welfare organisation to provide food to the poor, etc. Furthermore, the donors may then impose a specific condition to be met before the organisation is entitled to the donation, or the donor may specify what the organisation should do with the money donated (Flynne, Leo \& Addison, 2000). These conditions are often referred to as future performance conditions. From an accountability point of view, it is important that users of the financial statements are made aware of such restrictions and conditions attached to the donations (Flynne et al., 2000; Granof, 2001; Rossouw, 2006a).

These donations often pose challenges to the organisation in accounting for them, as there is no specific accounting standard dealing with these issues in South Africa. Non-profit organisations are then left to try to adapt principles which were meant for the business sector to recognise and measure donations. A lack of specific standards or guidelines may very well lead to diversity in practice. In its review of Australian non-profit organisations, the Institute of Chartered Accountants in Australia (2006) also found inconsistencies between organisations and inappropriate application of the principles for the recognition of donations received.

Two distinct approaches are that the donations are recognised as income when received, because the non-profit organisation could reasonably be expected to, in meeting its stated objective, use the donation as specified by the donor. The other approach may be described as "deferred until earned". Donations are recognised as income only when the specified conditions have been met (Institute of Chartered Accountants in Australia, 2006). The correct approach may also depend on the nature of the grant or donation. Some grants or donations may be reciprocal, while others are non-reciprocal. Grants received on the condition that specified 
services are delivered, or conditions fulfilled, can be described as "reciprocal". In some cases the donation is made to the organisation itself, with conditions attached to it, and in some cases the organisation is effectively doing something on behalf of the donor (Institute of Chartered Accountants in Australia, 2006:30).

The Australian standards for non-profit organisations include detailed specific guidance for the recognition of donations and grants. In terms of AASB 1004 Contributions (AASB, 2007), income from contributions is recognised only if, among other things, "the entity obtains contro/ of the contribution or the right to receive the contribution" (emphasis added). The standard then specifies that the "entity does not obtain control of a contribution ... until it has met conditions or provided services or facilities that make it eligible to receive a contribution" (emphasis added). From this, one can deduce that the two essential criteria for the recognition of donations as income are having control over the contribution and the contribution being recognised as income only when the performance conditions are met. If these criteria are not yet met, any money received would be deferred (as a liability). This approach is arguably in line with the current revenue recognition principle for businesses (IAS 18), although the lack of detailed criteria for the recognition of restricted donations may cause problems to the organisations and lead to diversity in practice, as was mentioned above. The views of accounting practitioners on these recognition criteria are presented in section 5.3 below.

Fund accounting is often related to the restricted donations and will be discussed next.

\subsection{Fund accounting}

So-called fund accounting may be another area in accounting that is unique to non-profit organisations (Mautz, 1989; Ives et al., 2004). With fund accounting specific items of income and expenses related to a particular fund (or activity) are recognised directly within a particular fund (directly into equity). The income and expenses are therefore not recognised through the income statement (or statement of surpluses or losses, first). Fund accounting implies that specific funds are separated from the rest of the organisation and separate accounts are used for separate funds. Separate financial statements could effectively be presented for each fund, as each fund is actually a separate accounting entity (Larkin \& DiTommaso, 2005; Rossouw, 2006b).

There may be various reasons why non-profit organisations would prefer this accounting treatment. Fund accounting allows them to separate restricted or specific funds from the normal general funds within the organisation. With fund accounting, donations that should be used for a specific project are recognised within a fund for that specific project and expenditures for that project are also recognised within that fund. This enables a non-profit organisation to indicate that they have complied with any restrictions placed on the donations (Mautz, 1989; Larkin \& DiTommaso, 2005; Wilson \& Kattelus, 2004). This approach also ensures that only the "general" funds are recognised in profit or loss (Flynn \& Koornhof, 2005).

It is important to note that IFRSs or IFRS for SMEs does not allow such a treatment. The standards require that all items of income or expenses are recognised in profit or loss, and some items are recognised in other comprehensive income. Only changes in accounting policies, correction of prior period errors and transactions with equity participants are recognised directly in equity (IASB, 2009, IASB, 2011d). This implies that non-profit organisations (for example, some companies) that are required to apply IFRSs or IFRS for SMEs would contravene the requirements of the Act if they were to apply fund accounting. The Australian accounting 
standards applicable to non-profit organisations do not include any requirements in respect of fund accounting, and it is deduced that it is therefore not allowed (Rossouw, 2006b) (i.e. the normal accounting principles are to be followed as indicated above).

In order to meet one of the objectives of this article - to provide empirical findings on the views of accounting practitioners - the respondents were informed what is meant by fund accounting and how it is applied. Their views are presented in section 5.4 below.

\section{EMPIRICAL RESEARCH}

\subsection{Research method}

In order to obtain the views of the accounting practitioners that are involved in the financial reporting of non-profit organisations in South Africa, empirical research was conducted to achieve the abovementioned research objectives (see section 2). Similar to related research on differential reporting in South Africa (Stainbank \& Wells, 2005 \&, 2007; Van Wyk \& Rossouw, 2009; Van Wyk \& Rossouw, 2011) (also compare Holmes, Kent \& Downey, 1991 in an Australian survey), accounting practitioners were selected as the population for the empirical research. Furthermore, accounting practitioners are assumed to be knowledgeable in accounting. As they are practically involved in the financial reporting of non-profit organisations (see section 4.2 below), it is assumed that they have an understanding of the implications of financial reporting for these organisations, and would be able to express an informed opinion on the questions posed to them in the survey (also compare Stainbank \& Wells, 2007).

During October and November 2011, a survey was conducted among accounting practitioners using a group-administered questionnaire (Trochim, 2006, Fraenkel \& Wallen, 2008:393). The questionnaires were completed by delegates attending various seminars across South Africa and internet-based "webinars" presented by the author on behalf of the South African Accounting Academy. The seminars dealt with the financial reporting of non-profit companies and nonprofit organisations (NPOs). The questionnaires were given to the delegates before each of the seminars and they would have been able to complete the questionnaire at any time during or after the seminars. This places a limitation on the findings of this study in that the respondents may have been influenced by discussions during the seminar. It is important to note that the seminar and the questionnaire refer to specific accounting concepts from the Australian financial reporting standards for non-profit organisations (refer to section 3). Providing the respondents with exposure to the content of the Australian standards should have enabled them to make more informed decisions on some aspects in the questionnaire. However, in order to obtain unbiased responses from the delegates, the presenter (author) did not express his own views on the aspects covered in the questionnaire. It is also important to note that the questionnaires did not address the technical accounting requirements for non-profit organisations themselves (as was addressed during the seminars), but rather the practitioners' views and perceptions on the identified aspects of the financial reporting of non-profit organisations (see the research objectives in section 2).

Choosing the accounting practitioners that attended the abovementioned seminars can be described as convenience sampling, as the sampling was done on the basis of the sample being accessible and expedient (Fraenkel \& Wallen, 2008; McMillan \& Schumacher, 2010). Furthermore, the sampling used in this research can also be described as purposeful sampling, as the respondents who were likely to be knowledgeable and informative about the topic of the 
research were chosen, as was explained above (Fraenkel \& Wallen, 2008; McMillan \& Schumacher, 2010). Both these sampling methods are non-random sampling (Fraenkel \& Wallen, 2008). Even though the finding of research that used these sampling methods may be useful, it is acknowledged that an inherent disadvantage of these sampling methods is that caution is needed when it comes to generalising the findings (Fraenkel \& Wallen, 2008; McMillan \& Schumacher, 2010).

This method was similar to prior related research on differential reporting (Van Wyk \& Rossouw, 2009 and Van Wyk \& Rossouw, 2011). Use of this method had the benefit of ensuring a higher number of completed questionnaires $(n=196)$ when compared to other prior research in the field of differential reporting in South African (Stainbank \& Wells, 2005 ( $n=64)$ and Stainbank \& Wells, $2007(n=64))$.

Through this qualitative research the author gained a deep understanding of the views and perceptions of the sample of accounting practitioners (Maykut \& Morehouse, 1994). Qualitative research is an organised and systematic exploration of some portion of human experience (the views of accounting practitioners, in the case of the present research) with the purpose of discovering common emergent themes (Donalek \& Soldwisch, 2004). The objective of this article is therefore to report on the common emergent theme of how the sample of accounting practitioners perceives some aspects of financial reporting of non-profit organisations.

\subsection{Data and analysis}

The respondents represent a wide spread of the geographic areas of South Africa, with most practitioners from the larger metropolis. The towns where the seminars were held (where the practitioners from that town and surrounding areas attended) are listed in TABLE 1 in alphabetical order below.

TABLE 1: Demographic information of the respondents

\begin{tabular}{|c|c|c|}
\hline Region & Frequency & Percentage \\
\hline Bloemfontein & 10 & $5 \%$ \\
\hline Cape Town / Somerset-West & 45 & $23 \%$ \\
\hline Durban & 26 & $13 \%$ \\
\hline Johannesburg & 39 & $20 \%$ \\
\hline Potchefstroom & 16 & $8 \%$ \\
\hline Pretoria & 52 & $27 \%$ \\
\hline Webinar through the internet (could be across South Africa) & 8 & $4 \%$ \\
\hline Total & 196 & $100 \%$ \\
\hline
\end{tabular}

Source: Author's calculations 
Rossouw

TABLE 2: Respondents' involvement in the financial reporting of non-profit organisations

\begin{tabular}{lcc}
\hline \multicolumn{1}{c}{ Involvement } & Frequency & Percentage \\
\hline Practitioners indeed involved with non-profit organisations & 182 & $93 \%$ \\
Practitioners not involved with non-profit organisations & 9 & $5 \%$ \\
Respondents did not complete this question & 5 & $2 \%$ \\
\hline Total & 196 & $100 \%$ \\
\hline
\end{tabular}

Source: Author's calculations

As the seminars dealt with the financial reporting of non-profit organisations in particular, it can be assumed that those respondents who did not indicate their involvement are in some or other way interested in this area. The high rating of involvement is a clear indication that the respondents have the necessary practical experience, insight and knowledge of the financial reporting of these organisations, and the respondents are well represented in this regard. It is acknowledged that a respondent can be involved in different ways with various non-profit organisations, and the respondents were therefore asked to indicate the one that best described their involvement. Their involvement is indicated in TABLE 3 below.

TABLE 3: Categories of respondents' involvement in the financial reporting of non-profit organisations

\begin{tabular}{lcc}
\hline \multicolumn{1}{c}{ Category } & Frequency & Percentage \\
\hline Auditor / independent reviewer & 56 & $29 \%$ \\
External (independent) preparer of the financial statements & 17 & $9 \%$ \\
Internal preparer of the financial statements & 13 & $7 \%$ \\
Accountant / bookkeeper of a non-profit organisation & 40 & $20 \%$ \\
General user of financial reports of non-profit organisation & 4 & $2 \%$ \\
Involved with regulator of non-profit organisations & 1 & $0.5 \%$ \\
Other involvement & 8 & $4 \%$ \\
Respondents choosing more than one of categories above & 56 & $28 \%$ \\
Did not respond & 1 & $0.5 \%$ \\
\hline Total & 196 & $100 \%$ \\
\hline
\end{tabular}

Source: Author's calculations

The data in TABLE 2 confirms that virtually all the respondents (93\%) are in some way or other (see TABLE 3) involved in the financial reporting of non-profit organisations. Even though the questionnaire clearly indicated that respondents had to choose only one category of involvement, $28 \%$ of them still marked more than one (i.e. the respondent may perhaps be an auditor of some non-profit organisations and an external preparer of financial statements for another, etc.). 
To establish the professional membership of the accounting practitioners, the respondents were also asked to indicate whether they are members of an accounting profession. The following professions were represented by the respondents.

TABLE 4: Accounting professions represented by respondents

\begin{tabular}{lcc}
\hline \multicolumn{1}{c}{ Profession } & Frequency & Percentage \\
\hline SA Institute of Chartered Accountants (SAICA) & 61 & $31 \%$ \\
SA Institute of Professional Accountants (SAIPA) & 55 & $28 \%$ \\
SA Institute of Business Accountants (SAIBA) & 7 & $3 \%$ \\
Chartered Association of Certified Accountants (ACCA) & 1 & $0.5 \%$ \\
SA Institute of Tax Practitioners & 4 & $2 \%$ \\
Other professions & 11 & $6 \%$ \\
Non-Member & 41 & $21 \%$ \\
Respondents choosing more than one of categories above & 15 & $8 \%$ \\
Did not respond & 1 & $0.5 \%$ \\
\hline Total & 196 & $100 \%$ \\
\hline
\end{tabular}

Source: Author's calculations

From TABLES 3 and 4 above one can deduce that the South African accounting professions are well represented by the respondents and the respondents are assumed to have the necessary practical experience and the knowledge to evaluate the financial reporting of non-profit organisations through their practical involvement with these organisations.

\section{RESEARCH FINDINGS}

The empirical findings of the views of the accounting practitioners on the areas identified in the research objectives are presented and discussed in this section. As with the literature review, this section is structured in the same sequence as that in which the research objectives were presented in section 2 above.

\subsection{Specific accounting principles for non-profit organisations}

Against the background of the literature review (in section 3.1 above), which suggested that specific accounting principles are needed for non-profit organisations, the accounting practitioners were asked whether they believe that specific and unique accounting standards or guidelines for non-profit organisation, dealing with specific accounting principles for these organisations, are needed. Their views are presented in TABLE 5. 
TABLE 5: The need for specific accounting standards for non-profit organisations

\begin{tabular}{lcc}
\hline \multicolumn{1}{c}{ Specific standards needed? } & Frequency & Percentage \\
\hline Yes, specific standards/guidelines are needed & 166 & $85 \%$ \\
No, specific standards/guidelines are not needed & 24 & $12 \%$ \\
Unsure & 4 & $2 \%$ \\
Did not respond & 2 & $1 \%$ \\
\hline Total & 196 & $100 \%$ \\
\hline
\end{tabular}

Source: Author's calculations

By far the majority of the accounting practitioners believed that specific accounting standards or guidelines are needed for non-profit organisations. The South African standard setters and regulating bodies should take note of this, and attention should be given to the financial reporting of non-profit organisations, especially those that are currently required to comply with IFRSs (according to the Companies Act). Any specific accounting standards or guidelines may be drafted in various formats, and this aspect is an area for future research.

\subsection{Recognition of assets and its service potential}

Future economic benefits may be regarded as synonymous with the notion of service potential, as was indicated in section 3.2 above. The implication of this is that assets with service potential (but with no economic benefits in the form of direct or indirect cash flows) may be recognised as assets in the financial statements of a non-profit organisation. The respondents were therefore asked whether they agree that, for non-profit reporting, the service potential of an asset may be a substitute for the future economic benefits of assets. The opinions of the accounting practitioners are as follows.

\section{TABLE 6: Service potential of assets}

\begin{tabular}{lcc}
\hline $\begin{array}{l}\text { May "service potential" be a substitute for "future economic } \\
\text { benefits" of assets of non-profit organisations? }\end{array}$ & Frequency & Percentage \\
\hline Yes & 152 & $78 \%$ \\
No & 16 & $8 \%$ \\
Unsure & 21 & $11 \%$ \\
Did not respond & 7 & $3 \%$ \\
\hline Total & 196 & $100 \%$ \\
\hline
\end{tabular}

Source: Author's calculations

The majority of the respondents are of the opinion that the service potential of an asset may be a substitute for the concept of future economic benefits of assets for non-profit organisations. The results of this research are similar to those of prior research (Rossouw, 2008), where it was found that $80 \%$ of the respondents of a specific type of religious non-profit organisation 
believed that assets that embody service potential should still be recognised as assets, even though they failed to meet the criteria of economic benefit per the definition of an asset.

This would be a major point of reference for the development of specific accounting principles for non-profit organisations. It could be deduced that this concept would impact the initial recognition of items as assets (for example, property, plant and equipment, inventory and other assets); the classification of assets (a distinction should thus be made between assets that generate future economic benefits and assets that are mainly kept for their service potential rather than economic benefit); and the measurement of assets (mainly as far as they relate to impairment of inventory to net realisable value and other assets to value in use or depreciated replacement cost) as was explained in section 3.2 above.

\subsection{Recognition of donations as income}

Following the detailed criteria for the recognition of donations as was discussed in section 3.3 above, the respondents were asked whether they agree that donations may only be recognised as income when the entity has control over the donation and the performance conditions are met. TABLE 7 below shows the view of the respondents.

\section{TABLE 7: Recognition of restricted donations}

\begin{tabular}{lrc}
\hline $\begin{array}{l}\text { Should donations be recognised as income only when the entity has } \\
\text { control over the donation and the performance conditions are met? }\end{array}$ & Frequency & Percentage \\
\hline Yes & 169 & $86 \%$ \\
No & 14 & $7 \%$ \\
Unsure & 9 & $5 \%$ \\
Did not respond & 4 & $2 \%$ \\
\hline Total & 196 & $100 \%$ \\
\hline
\end{tabular}

Source: Author's calculations

The majority of the respondents are of the view that donations to which future performance conditions are attached should be recognised as income only when the entity has control over the donation and the performance conditions are met. The respondents therefore agree specifically with the Australian standard applicable to non-profit organisations, which is arguably in line with the general revenue recognition principles as contained in IAS 18. To put this further in context, this treatment is also in line with the requirements of the IFRS for SMEs for the recognition of government grants, which is arguably the closest transaction to a donation. In terms of the IFRS for SMEs, a "grant that imposes specified future performance conditions on the recipient is recognised in income only when the performance conditions are met" (IASB, 2009).

\subsection{Fund accounting}

The nature of the so-called "fund accounting" was discussed in the literature review (in section 3.4 above). In terms of Accounting Standards, fund accounting is not allowed, but it still remains quite common among non-profit organisations. The respondents were then asked to 
indicate their views on this matter. The respondents were asked to indicate whether fund accounting should be allowed for all non-profit organisations or only for those organisations for which current legislation does not prohibit it (i.e. the Companies Act, which requires IFRSs or IFRS for SMEs). Their responses are summarised in TABLE 8.

TABLE 8: Qualifying entities for fund accounting

Should "fund accounting" be allowed for non-profit organisations?

Fund accounting should be allowed for all non-profit organisations, irrespective of its legal form, size, its "public interest score", etc.

Fund accounting should only be allowed for non-profit organisations, which are not legally required to follow IFRSS or IFRS for SMEs under the Companies Regulations (i.e. organisations not in the legal form of a company and companies with lowest level of "public interest score")

Fund accounting should not be allowed for any non-profit organisation.

Unsure

Did not respond
Frequency Percentage

93

$48 \%$

$20 \%$

40

$16 \%$

$32 \quad 16 \%$

$25 \quad 13 \%$

Total

196

$100 \%$

\section{Source: Author's calculations}

A total of $68 \%$ ( $48 \%$ plus $20 \%$ ) of the respondents were of the opinion that fund accounting should be allowed for non-profit organisations, while only $16 \%$ believe that fund accounting should not be allowed. The category that received the most votes (48\%) from the respondents is that all non-profit organisations, irrespective of legal form, size, "public interest score", etc., should be allowed to apply fund accounting, although this does not represent the majority of the respondents. The views of the accounting practitioners are therefore in conflict with the specific Australian standards for non-profit organisations and IFRSs.

Given that the respondents were somewhat divided on this aspect, the need for fund accounting needs to be researched further. Fund accounting can also be achieved in a number of ways. However, the best approach to be followed for fund accounting is also an area for future research and is not addressed in this article.

\section{SUMMARY AND CONCLUSION}

Financial reporting standards such as the IFRSs may not have been designed to be specifically applicable to non-profit organisations. However, legislation in some cases does require compliance with IFRSs or IFRS for SMEs. The purpose of this article was to provide a literature review and empirical data on accounting practitioners' views on the following aspects relating to the financial reporting of non-profit organisations:

- the need for specific accounting principles for non-profit organisations;

- the recognition of assets with no future economic benefits, but with service potential;

- the recognition of restricted donations; and 
- fund accounting.

In order to meet these objectives a literature review was conducted and the requirements of the Australian accounting standards issued specifically for non-profit organisation were analysed. The views of accounting practitioners were gathered using a group-administered questionnaire.

The empirical findings confirmed the literature review that suggested that specific accounting principles for non-profit organisations are needed, that assets with no economic benefits but with service potential may be recognised as such, and that restricted donations may be recognised only once earned. The sample of accounting practitioners generally believes that specific accounting standards or guidelines are needed to meet the financial reporting needs of non-profit organisations in South Africa. These accountants also believe that an asset's service potential may be a substitute for future economic benefits in the recognition and measurement of assets of non-profit organisations as is allowed by the Australian standards for non-profit organisations. The accounting practitioners also agreed with the Australian standards for nonprofit organisations in that they believe that donations and especially donations with conditions attached to them can only be recognised as income when the organisation has control over the donation and the performance conditions are met. However, in contrast with the literature and specifically the Australian standards for non-profit organisations, the practitioners are of the opinion that fund accounting should generally be allowed for all types of non-profit organisations.

\section{LIMITATIONS AND RECOMMENDATIONS FOR FUTURE RESEARCH}

As mentioned in the section for the research methodology the fact that the respondents attended a seminar on the financial reporting of non-profit organisations (convenience and purposeful sampling) may place a limitation on the generalisation of the findings of this research. The respondents may have been influenced by the discussions during the seminar, even though the author did not express his own views on the aspects researched. Furthermore, the accounting practitioners were asked to give their own views on the aspects researched.

The need for specific accounting standards or guidelines for non-profit organisations is related to the general concept of differential reporting. It is suggested that future research could be conducted to identify whether differential reporting is acceptable on the basis of the unique nature of these organisations and how best to incorporate specific accounting principles in financial reporting standards. The specific format of specific or alternative accounting principles for non-profit organisations could be achieved in different ways - for example, by amending IFRSs or by issuing separate standards for non-profit organisations. The actual format of specific accounting principles for non-profit organisation is an area for future research.

In light of the fact that the practitioners believe that fund accounting should be allowed even though accounting standards do not allow such treatment, future research could be conducted on whether fund accounting is appropriate and to explore various ways in which it could effectively be achieved. Differentiating the financial reporting of public sector non-profit organisations from those in private sector is also an area of future research. In relation to this, future research could consider analysing GRAP in detail in addressing the problem areas identified. 


\section{LIST OF REFERENCES}

$A A S B$, vide Australian Accounting Standards Board.

$A S B$, vide Accounting Standards Board (of South Africa).

$A S R B$, vide Accounting Standards Review Board (of Australia).

Accounting Standards Review Board (ASRB). (2009). ASRB Release 8: The Role Of The Accounting Standards Review Board And The Nature Of Approved Financial Reporting Standards. [Online] Available: www.nzica.com/.../ASRB\%20Release\%208\%20-\%202009.ashx (Accessed 20 June 2012).

Accounting Standards Board (ASB). (2012a). Reporting Framework at a g/ance. [Online] Available: http://download.asb.co.za/REPORTING\%20FRAMEWORKS\%20AT\%20A\%20GLANCE\%202012\%20(revise d\%2024\%20January\%202012).pdf (Accessed 22 August 2012).

Accounting Standards Board (ASB). (2012b). GRAP I Presentation of financial statements. [Online] Available:

http://download2.asb.co.za/standards/GRAP\%201\%20Presentation\%20of\%20Financial\%20Stateme nts\%20(March\%202012)(clean\%20copy).pdf (Accessed 22 August 2012).

Australian Accounting Standards Board (AASB). (2007.) AASB 1004 Contributions. [Online] Available: http://www.aasb.gov.au/admin/file/content105/c9/AASB1004_12-07.pdf (Accessed 2 September 2011)

Australian Accounting Standards Board (AASB). (2009). Process for modifying IFRSs for PBE/NFP. [Online] Available:

http://www.aasb.gov.au/admin/file/content102/c3/final_process_for_modifying_ifrss_oct_2009.p df. (Accessed 20 June 2012).

Australian Accounting Standards Board (AASB). (2011). Accounting Standards. [Online] Available: http://www.aasb.gov.au/Pronouncements/Current-standards.aspx (Accessed 2 September 2011).

Carson, C. (2008). Separate financial reporting standards for NFPs. Chartered Accountants Journal, $87(5): 22-24$

Department of Social Development. (2005). Assessment of NPO Act. [Online] Available: http://www.dsd.gov.za/npo/index.php?option=com_docman\&task=cat_view\&gid=27\&ltemid=116 (Accessed 21 August 2012).

Donalek, J.G. \& Soldwisch, S. (2004). Demystifying nursing research: an introduction to qualitative research methods. Urologic Nursing, 24(4), pp. 354-356.

Flynn, D. \& Koornhof, C. (2005). Fundamental Accounting. Kenwyn: Juta\&Co.

Flynne S., Leo K. \& Addison P. (2000). Financial Reporting by Not-for-profit Entities. Melbourne: CPA Australia. [Online] Available: http://www.cpaonline.com.au/ (Accessed 14 January 2002).

Fraenkel, J.R. \& Wallen, N.E. (2008). How to design and evaluate research in education. New York: McGraw-Hill Higher Education.

Granof, M.H. (2001). Government and not-for-profit accounting - concepts and practices. New York: John Wiley \& Sons.

Holmes, S., Kent, P. \& Downey, G. (1991). The Australian differential reporting debate - a survey of practitioners. Accounting \& Business Research, 82(21), pp. 125-132. 
Institute of Chartered Accountants in Australia. (2006). Not-For-Profit Sector Reporting: A Research Project. New South Wales: Institute Of Chartered Accountants In Australia. [Online] Available: Http://Www.Charteredaccountants.Com.Au/Industry-Topics/Reporting/Current-Issues/Not-ForProfit (Accessed 5 October 2011).

International Accounting Standards Board (IASB). (2009). International Financial Reporting Standard for Small and Medium-sized entities. London: IFRS Foundation.

International Accounting Standards Board (IASB). (2010). The Conceptual Framework for Financial Reporting. London: IFRS Foundation.

International Accounting Standards Board (IASB). (2011a). IAS 8 Accounting Policies, Changes in Accounting Estimates and Errors. London: IFRS Foundation.

International Accounting Standards Board (IASB). (2011b). Preface to International Financial Reporting Standards. London: IFRS Foundation.

International Accounting Standards Board (IASB). (2011c). International Financial Reporting Standards. London: IFRS Foundation.

International Accounting Standards Board (IASB). (2011d). IAS 1 Presentation of Financial Statements. London: IFRS Foundation.

Ives, M., Razek, J.R. \& Hosch, G.A. (2004). Introduction to Governmental and Not-for-Profit Accounting. Upper Saddle River: Pearson Prentice Hall.

Larkin, R.F. \& DiTommaso, M. (2005). Wiley Not-for-Profit GAAP 2005 - Interpretations and Application of Generally Accepted Accounting Principles for Not-for-Profit Organisations. Hoboken: John Wiley \& Sons, Inc.

Lee, S. \& Teixeira, A. (2004). Implications of IFRS for sector-neutral standard setting. Chartered accountants journal, 83(6), pp. 21-24.

Leo, K. \& Addison, P. (2000). Help at hand for charities. Australian CPA 70(7), pp. 56-58.

Mautz, R.K. (1989). Not-for-profit financial reporting: Another view. Journal of Accountancy, 168(2), pp. 60-66.

Mautz, R.K. (1994). Financial reporting for non-profit organisations - a fresh look. New York and London: Garland.

Maykut, P. \& Morehouse, R. (1994). Beginning qualitative research: a philosophic and practical guide. London \& Washington: Falmer Press.

McMillan, J.H. \& Schumacher, S. (2010). Research in Education. Evidence-based inquiry. Upper Saddle River: Pearson.

Rossouw, J. (2006a). Algemeen Aanvaarde Rekeningkundige Praktyk vir Niewinsgewende Organisasies, met verwysing na die NG Kerk in die Vrystaat. (Translated: Generally Accepted Accounting Practice for Non-profit organisations, with reference to the Dutch Reformed Church in the Free State. (Unpublished Masters' dissertation.) University of the Free State, Bloemfontein.

Rossouw, J. (2006b). Accounting requirements for donor-imposed restrictions and the restricted funds of not-for-profit organisations. Meditari Accountancy Research, 14(2), pp. 33-49.

Rossouw, J. (2007). Recognition of restricted receipts by not-for-profit organisations: problems, standards and empirical results. Meditari Accountancy Research, 15(1), pp. 71-89. 
Rossouw, J. (2008). Die Rekeningkundige erkenning van bates en verwante uitgawe deur niewinsgewende organisasies met verwysing na die NG Gemeentes in die Vrystaat. Tydskrif vir Christelike Wetenskap, 44(1), pp. 79-100.

RSA vide Republic of South Africa.

Republic of South Africa. (1997). Nomprofit Organisations Act, Act 71 of 1997. Pretoria: Government Gazette.

Republic of South Africa. (2008). Companies Act, Act 71 of 2008. Pretoria: Government Gazette.

Republic of South Africa. (2011). Companies Regulations, 2011. Pretoria: Government Gazette.

Stainbank, L. \& Wells, M. (2005). Differential corporate reporting in South Africa - the state of the art. Meditari Accountancy Research, 13(1), pp. 51-65.

Stainbank, L. \& Wells, M.J.C. (2007). Differential corporate reporting: registered accountants' and auditors' views in South Africa. South African Journal of Accounting Research, 21(1), pp. 31-55.

Trochim, W.M. (2006). The Research Methods Knowledge Base. Types of surveys. [Online] Available: http://www.socialresearchmethods.net/kb/survtype.php. (Accessed 14 January 2010).

Van Wyk, H.A. \& Rossouw, J. (2009). IFRS for SMEs in South Africa: a giant leap for accounting, but too big for smaller entities in general. Meditari Accountancy Research, 17(1), pp. 99-116.

Van Wyk, H.A. \& Rossouw, J. (2011). Accounting practitioners' views on the proposed "micro gaap" - a South African perspective. Journal of Economic \& Financial Sciences, 4(2), pp. 257-273.

Wilson, E.R. \& Kattelus, S.C. (2004). Accounting for Governmental and Nonprofit Entities. New York: McGraw-Hill/Irwin. 